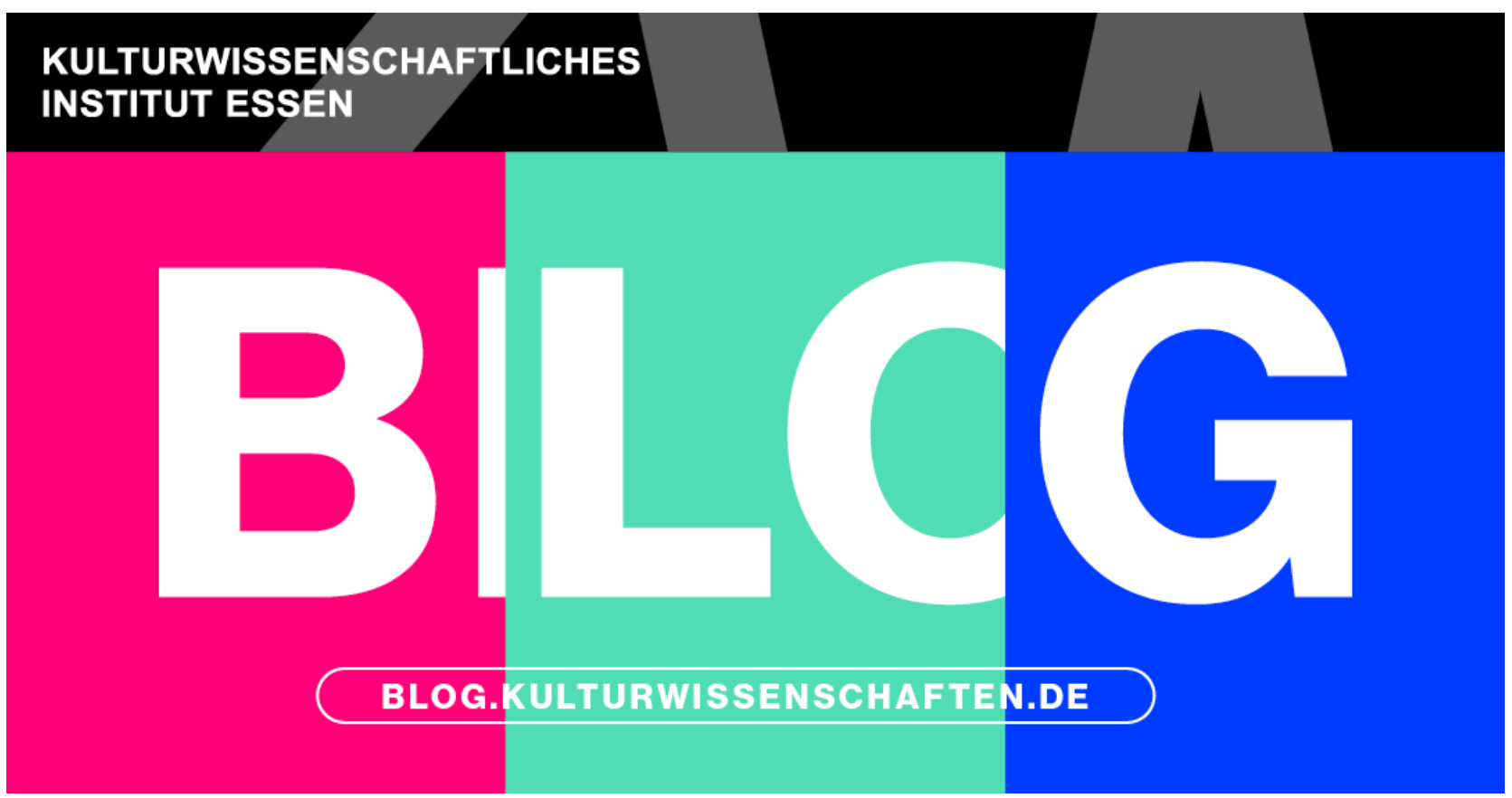

\title{
At the sports ground, with footnotes (III) America's Athletic Democracy
}

Erschienen in: WORTATLAS

Von: Danilo Scholz

While sports languish in relative obscurity in Germany's universities, the importance of college athletics to American culture can hardly be overstated. In the United States, the stadium, track, baseball field, and basketball court are linchpins of much undergraduate life. Their pageants may lure 100,000 or more spectators, as can be witnessed at any home game of the Wolverines, the University of Michigan football team - a turn-out inconceivable at any university-related sporting event in Germany. The National Collegiate Athletic Association (NCAA) represents more than 500,000 athletes across two dozen disciplines at more than 1,000 universities and colleges throughout the US. As Andrei S. Markovits and Lars Rensmann have observed, the phenomenon of college sports constitutes "an exception in contemporary American culture that is truly unique and unparalleled anywhere in the world". ${ }^{1}$ Extraordinary for its power to engross spectators and millions-strong TV audiences alike, it is also unusual because the rest of the world has remained largely impervious to its domestic clout.

From the nineteenth century on, the cultural imaginary of the United States has been suffused with paeans to the fitness of the body politic. Walt Whitman characterised the nation as an "athletic democracy," and its citizens as "freedom's athletes". 2 Democracy, far from being restricted to a small number of governing institutions, quickened the pulse of every member of American society in this idealised vision; it was, Whitman wrote, "life's gymnasium". ${ }^{3}$ Yet to dismiss these effusions as poetic flights of fancy or mere metaphors 
is to overlook how firmly they were anchored in lived sporting experience. Whitman, after all, eulogised "a good game of base-ball" as one of the quintessential American pursuits in the earliest version of his poem "Song of Myself" published in 1855. ${ }^{4} \mathrm{He}$ even covered the odd game as a sports reporter. Likewise, Mark Twain saluted baseball as the "very symbol, the outward and visible expression, of the drive and push and rush and struggle of the raging, tearing, booming nineteenth century". ${ }^{5}$ Baseball, however, was soon pushed off its pedestal by a rival sport.

By the 1890s, rugby, in its American guise, became the dominant college sport in the US. Arguably no one did more for its rise to prominence, its definitive departure from its British origins and its transformation into a commercially lucrative activity than Walter Camp, who had played for Yale and acted as an influential advisor to the team during its heyday in the 1880s and 1890s. He was also the driving force behind some of the most consequential rule changes, which birthed the position of the quarterback and led to the introduction of the five-yard chalk lines on the field, creating the "gridiron" effect that to this day makes American football instantly recognisable even to non-initiates. Under the stewardship of Camp, widely acknowledged as the "Father of American Football", the sport came to revolve around the clash of mass formations as one side strove to gain five yards (or more) over their opponents.

Meanwhile, university administrators worried about the risk of injury in a game they considered not just physically demanding, but plain brutal. In the late nineteenth century, one in five ex-players reported permanent injuries. Camp chose to conceal such findings as he compiled Football Facts and Figures to assuage public concerns about the game's safety. A Harvard graduate named Theodore Roosevelt, who had not yet been elevated to the White House, wrote to Camp to express his disgust that Harvard's president was seriously countenancing a ban on football. Roosevelt, an ardent advocate of a muscular virility in sports as well as politics, assured his correspondent in 1895 that he "would a hundred fold rather keep the game as it is now, with the brutality, than give it up". 6 The Republican politician Henry Cabot Lodge, a close friend of Roosevelt's, could not have agreed more. Addressing the Harvard class of 1896, Lodge contended that the time "given to athletic contests and the injuries incurred on the playing field are part of the price which the English-speaking race has paid for being world-conquerors". ${ }^{7}$ In a speech given two years before he was elected president, Roosevelt resorted to football imagery to illustrate his call for "the life of strenuous endeavour", held up as an ideal to his fellow countrymen. "Hit the line hard: don't foul and don't shirk, but hit the line hard". ${ }^{8}$

Others had fewer qualms about cheating. They lionised American football as a proving ground, toughening up the nation's freshmen for the Darwinian world of US-style capitalism. "The spirit of the American youth, as of the American man", the editor of the Nation claimed in 1890, "is to win, to 'get there', by fair means or foul; and lack of moral scruple which pervades the struggles of the business world meets with temptations equally irresistible in the miniature contests of the football field". ${ }^{9}$ Politicians, too, ought to know when to land a low blow. One John C. Loveland considered football a great asset for "the man of the future" who "must be able to elbow his way" in the "foul air of primary elections": he "may need to 'tackle' an anarchist now and then and perhaps oftener". 10 
Eventually, the casualties spoke for themselves. In 1904 alone, twenty-one players were killed on the football field. Shocked by the sight of crushed bodies during a match between the University of Pennsylvania and Swarthmore College, even Roosevelt changed tack, urging rule changes to make the game safer. But no matter how many reforms were instituted, the association between football and violence persisted. Don DeLillo sublimated it into a literary monument to the sport in his 1972 novel End Zone. It is testament to DeLillo's metafictional panache that two protagonists in the book explicitly dismiss the facile equation of football and carnage, only to be implicitly overridden by the author's lyrical evocations of bodies in athletic combat. Zapalac, a biology lecturer at the fictional Logos College in Texas, rejects the notion of football as warfare out of hand: "Warfare is warfare. We don't need substitutes because we've got the real thing. Football is discipline. It's team love. It's reason plus passion." 11 Emmett Creed, head coach of the Screaming Eagles, the college's football team, expatiates in a similar vein: "People stress the violence. That's the smallest part of it. Football is brutal only from a distance. In the middle, there's a calm, a tranquillity." 12 Yet here is DeLillo swooning over how two "teams collided, swarm and thud of interchangeable bodies, small wars commencing here and there, exaltation and firstblood, a helmet bouncing brightly on the splendid grass, the breathless impact of two destructive masses, quite pretty to watch". ${ }^{13}$

Money - feared for its corrupting influence, eagerly accepted for its performanceenhancing potential - was another thorny issue. Educational prestige and financial power, never too far apart to begin with, fully merged during the 1880s and 1890s on the occasion of the Thanksgiving football match hosted at New York City's Polo Grounds. On the pitch, student teams from top-tier colleges such as Princeton and Yale vied for supremacy. Among the fashionable thousand-strong audience in the stands, representatives of the East Coast elite gathered for one of the more coveted social events in Gilded Age America. Many other colleges, who spotted a lucrative opportunity to rake in funds through ticket sales, hosted similar Thanksgiving Day games at their sports grounds. In 1905 a former Yale student turned journalist uncovered that Yale disposed of an athletic reserve fund worth $\$ 100,000$ and that sports, especially ticket sales, accounted for one eighth of the university's revenue.

At the turn of the twentieth century, coaches were already earning more than the highestpaid professors, and the gulf between the two would only continue to widen. In 1905, a time when annual wages for the average worker hovered around $\$ 500$, Columbia football coach George Foster was paid $\$ 5,000$ - a sum which, allowing for inflation, would amount to more than $\$ 150,000$ today. The perceived need for salaried coaches arose from within a student body bent on leaving their rivals in the dust and more than willing to solicit professional help to achieve that goal. Only Harvard, more indebted to the upperclass British embrace of amateur sports, remained a holdout against professional coaches. "It's not pleasant to be beaten by Yale year after year", lamented a student magazine in 1903. "All Harvard men want to win our full share of victories, but, after all, the ultimate end of athletics is not to defeat Yale. If it were, then the employment of a professional coach would be wise". ${ }^{14}$ The resistance to such a move crumbled as other college teams pulled ahead; even Harvard - especially Harvard - was not immune to the lure of winning at all costs. 
While the spirit of professionalism permeated intercollegiate sports in the US early on, most participants in the system feigned adherence to the letter if not the spirit of the amateur ideal. It was and is an uneasy coexistence rife with hypocrisy and rotten compromises. Foregoing the advantages of professional training and infrastructure condemned colleges to athletic insignificance. Renouncing the amateur creed altogether would damage their standing. The only ones consistently forbidden from accepting remuneration were the players. This prohibition covered not only their performance but also rights to their name, image, and likeness, thanks to which others laughed all the way to the bank - at least until now. In the summer of 2021, a much-anticipated Supreme Court ruling forced the hand of the NCAA and cleared the legal ground for college athletes to appear in advertisements and be paid for public appearances.

Broadcasting rights and sports manufacturers paying handsomely to kit out teams had only exacerbated the tension. With the launch of the ESPN in 1979, the commercialisation of college football took on an entirely new dimension. As the rights to broadcast professional leagues were as yet out of reach for the sports channel, its executives struck a deal with the NCAA. All of a sudden, sports that, supposedly, were not for profit became flush with advertising and media revenue. According to figures compiled by Forbes, in 2019 the twenty-five most valuable college football teams boasted combined annual revenues of $\$ 2.7$ billion. In 2016, the University of Michigan football team severed ties with its outfitter Adidas and finalised a fifteen-year deal with Nike worth nearly $\$ 174$ million. ESPN and Fox Sports split between themselves the $\$ 440$ million they have to cough up every year for the TV rights to the Big Ten Conference, the oldest college football league in the US.

Always a prescient chronicler of the twists and turns of US society, DeLillo foresaw and lampooned the intrusion of money into every nook and cranny of "amateur" college athletics - right down to the contortions of PR speak. After losing the decisive game of the season, the Logos College football coach hires a "sports information director" who, despite not having the least inkling about the game, has grand plans for the team. "I'll tell you the honest truth. What I know about football you can inscribe with a blunt crayon around the rim of a shot glass. I don't know squat about football. I'm an indoors man. But I know the whys and wherefores of the entertainment dollar. People want spectacle plus personality." 15

\section{References}

1. Andrei S. Markovits and Lars Rensmann, Gaming the World: How Sports Are Reshaping Global Culture, Princeton: Princeton University Press, 2010, p. 272. https://doi.org/10.1515/9781400834662.

2. Walt Whitman, "To Foreign Lands" (1881/82), Leaves of Grass, in The Complete Writings of Walt Whitman, vol. 1, New York: G. P. Putnam's Sons, 1902, p. 4; Walt Whitman, Democratic Vistas (1871), in The Complete Writings of Walt Whitman, vol. 5 , p. 85 .

3. Walt Whitman, Democratic Vistas, p. 85. 
4. Walt Whitman, "Song of Myself", Leaves of Grass, p. 75.

5. Samuel L. Clemens (ed.), Mark Twain's Speeches, New York: Harper \& Brothers, 1923, p. 145.

6. Ronald A. Smith, Sports and Freedom: The Rise of Big-Time College Athletics, New York: Oxford University Press, 1988, p. 95-96.

7. Quoted in Kristin Hoganson, Fighting for American Manhood: How Gender Politics Provoked the Spanish-American and Philippine-American Wars. New Haven: Yale University Press, 1998, p. 37.

8. Theodor Roosevelt, The Strenuous Life: Essays and Addresses, New York: The Century, 1900, p. 20, 164.

9. Quoted in Ronald A. Smith, Sports and Freedom, p. 98.

10. Walter Camp, Football Facts and Figures, New York: Harper and Brothers, 1894, p. 47.

11. Don DeLillo, End Zone, New York: Penguin, 1986, orig. published in 1972, p. 164.

12. Ibid., p. 199.

13. Ibid., p. 164.

14. Quoted in Ronald A. Smith, Sports and Freedom, p. 163-164.

15. Don DeLillo, End Zone, p. 151.

SUGGESTED CITATION: Scholz, Danilo: At the sports ground, with footnotes (III): America's Athletic Democracy, in: KWI-BLOG, [https://blog.kulturwissenschaften.de/atthe-sports-ground-with-footnotes-iii/], 20.12.2021

DOI: https://doi.org/10.37189/kwi-blog/20211220-0830 
This text is made available via DuEPublico, the institutional repository of the University of Duisburg-Essen. This version may eventually differ from another version distributed by a commercial publisher.

DOI: $\quad 10.37189 / \mathrm{kwi}-\mathrm{blog} / 20211220-0830$

URN: urn:nbn:de:hbz:464-20211220-085338-1 